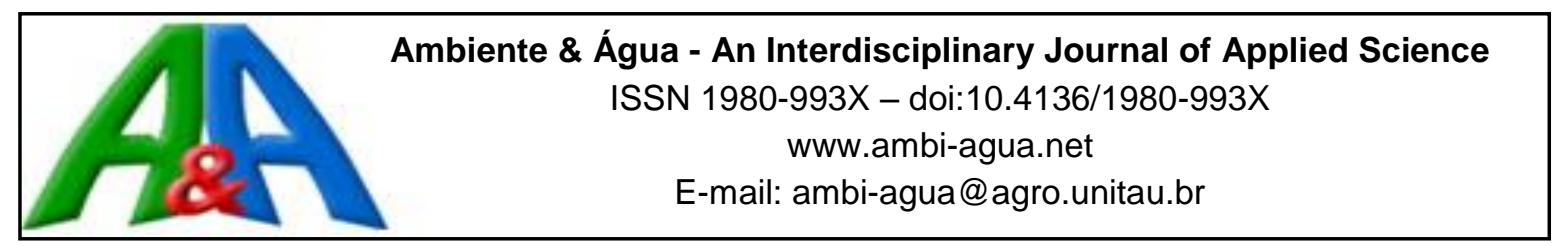

\title{
Air pollutants and hospital admissions due to stroke
}

\author{
doi: 10.4136/ambi-agua.1318
}

Received: 14 Feb. 2014; Accepted: 07 Jul 2014

\author{
Samara Gavinier; Luiz Fernando Costa Nascimento* \\ Universidade de Taubaté (UNITAU), Taubaté, SP, Brasil \\ *Corresponding author: e-mail: luiz.nascimento@unitau.com.br, \\ sagavinier@yahoo.com.br
}

\begin{abstract}
International studies have demonstrated associations between exposure to air pollutants and deaths and hospitalizations due to stroke. However, the profile of these associations is not known in Brazil. This study aims to estimate the association between exposure to air pollutants and hospital admissions due to stroke in individuals who live in a medium-sized city, Sorocaba, Sao Paulo, Brazil. This was ecological time-series study using hospitalization data relating to the diagnosis of stroke (ICD-10 I.60-I.64) in persons 50 years of age or older who resided in the city of Sorocaba between January 1, 2007 to December 31, 2011. The pollutants studied were particulate matter, ozone, nitrogen dioxide and nitrogen oxide, controlled by apparent temperature. The generalized additive model using Poisson regression for the day of hospitalization and for up to five days of lag was used for the analysis. It was not possible to estimate the association between exposure to daily levels of particulate matter, ozone and nitrogen oxide and hospitalizations for strokes, but it was possible to identify an association between exposure to nitrogen dioxide and hospitalization for stroke $(\mathrm{RR}=1.004$, 95\% CI 1.000-1.008) for the third one-day lag. An increase of $10 \mu \mathrm{g} \mathrm{m}^{-3}$ in concentrations of this pollutant represented an increase of 4 percentage points in the risk of hospitalization. Thus, it was established that the nitrogen dioxide is associated with hospitalization for stroke in a medium-sized city, i.e., Sorocaba.
\end{abstract}

Keywords: air pollution, stroke, time series studies, nitrogen dioxide.

\section{Poluentes atmosféricos e internações por acidente vascular encefálico}

\section{RESUMO}

Estudos internacionais demonstram associações entre exposição a poluentes do ar e óbitos e internações por AVE. Entretanto, não é conhecido o perfil dessas associações no Brasil. O presente estudo tem por objetivo estimar a associação entre a exposição a poluentes do ar e as hospitalizações por acidente vascular encefálico em indivíduos residentes de um município de porte médio, Sorocaba, São Paulo, Brasil. Realizou-se um estudo ecológico de série temporal com dados de internações por diagnóstico de acidente vascular encefálico (CID-10 I.60-I.64), em indivíduos com 50 anos de idade ou mais, residentes no município de Sorocaba, durante o período de 1 de janeiro de 2007 a 31 de dezembro de 2011. Os poluentes estudados foram o material particulado, o ozônio, o dióxido de nitrogênio e o óxido de nitrogênio, controlados pela temperatura aparente. Para a análise, foi utilizado o modelo 
aditivo generalizado pela regressão de Poisson para o dia da internação e para até cinco dias de defasagens. Não foi possível estimar associação entre a exposição aos níveis diários do material particulado, do ozônio e do óxido de nitrogênio e internações por AVE. Mas, foi possível identificar associação entre exposição ao dióxido de nitrogênio e a internação por acidente vascular encefálico $(\mathrm{RR}=1,004$; IC95\% 1,000- 1,008), para o terceiro dia de defasagem. $\mathrm{O}$ incremento de $10 \mu \mathrm{g} \mathrm{m} \mathrm{-}^{3}$ nas concentrações desse poluente representou um aumento de 4 pontos percentuais no risco de internação. Assim, foi possível identificar o dióxido de nitrogênio está associado à hospitalização por acidente vascular encefálico em uma cidade de médio porte, Sorocaba.

Palavras-chave: poluição do ar, acidente vascular cerebral, série temporal, dióxido de nitrogênio.

\section{INTRODUCTION}

Several studies have shown the harmful effects of air pollutants on human health. These studies have found that concentrations of air pollutants below the limit established by national and international governmental standards may significantly impact health (Brazil, 1990; Gouveia et al., 2006; Olmo et al., 2011).

Gaseous pollutants and inhalable particulate matter have acute and chronic effects on respiratory diseases (Cançado et al., 2006; Braga et al., 2007; Ignotti et al., 2010; Amancio and Nascimento, 2012), particularly in children and elderly people; they also significantly impact persons with cardiovascular disease (Cançado et al., 2006; Cendon et al., 2006; Braga et al., 2007; Nascimento, 2011; Gavinier and Nascimento, 2013). Data from hospital admissions, emergency care and mortality have been used to assess such effects.

The main emission sources of air pollutants are the burning of biomass, industries and motor vehicles (Harrison, 2006). The importance of studying the concentration of air pollutants in large cities is apparent, since these areas are heavily industrialized and have heavy vehicular traffic on both highways and in urban areas. However, few studies explore the effects of these pollutants in medium-sized cities.

Recently, three studies conducted in medium-sized Brazilian cities showed significant associations between air pollutant exposure and asthma hospitalization (Amancio and Nascimento, 2012), hospital admissions for ischemic heart disease (Nascimento, 2011) and hospitalization due to stroke (Nascimento et al., 2012).

Stroke is responsible for more morbidity and mortality than any other cardiovascular disease, and is considered the second leading cause of death worldwide (Donnan et al., 2008). Among Latin American countries, Brazil has considerable rates of mortality due to stroke (Lotufo, 2005).

In the year 2009, around 150,000 hospital admissions due to stroke occurred throughout Brazil. These resulted in about 30,000 deaths, with a cost to the national coffers of around $\mathrm{R} \$$ 240 million ( 1 US $\$ \approx \mathrm{R} \$ 2.00$ ). In the state of São Paulo alone, about 40,000 hospital admissions were due to stroke. Mortality rates for that year were 18.98 per 100,000 inhabitants for Brazil and 20.64 for the state of São Paulo (Brazil, 2013).

Two international studies suggest plausible physiopathological relations. The exposure of individuals to high levels of air pollutants can aggravate or even trigger two possible mechanisms in the pathogenesis of cardiovascular disease (Brook et al., 2004; Pope et al., 2004).

One of these mechanisms involves systemic inflammation responsible for changes in coagulation, increased blood viscosity and the progression of atherosclerosis. Another mechanism involves the autonomic cardiac function, responsible for reducing the variability of heart rate, vasoconstriction and increased blood pressure. Such direct and indirect effects of 
air pollution present a plausible explanation for the occurrence of a sudden cardiovascular response, such as a stroke (Brook et al., 2004; Pope et al., 2004).

International studies have shown associations between air pollutants and deaths due to stroke (Hong et al., 2002.), as well as hospitalizations due to strokes (Hong et al., 2002; Tsai et al., 2003; Wellenius et al., 2005; Johnson et al., 2010); however, only one national study has been conducted (Nascimento et al., 2012).

This study therefore aims to estimate the association between daily exposure to air pollutants and hospital admissions for ischemic or hemorrhagic strokes in the residents of Sorocaba, São Paulo, Brazil, a medium-sized city.

\section{MATERIAL AND METHODS}

This was an ecological time-series study that used data from daily admissions of both sexes due to stroke in Sorocaba, Sao Paulo, Brazil. Stroke diagnosis (I60 - I64) was determined according to the $10^{\text {th }}$ revision of the International Classification of Diseases. Sorocaba is considered a medium-size city, located in the southwestern region of the state of São Paulo, $90 \mathrm{~km}$ from São Paulo at latitude $23^{\circ} 30^{\prime}$ South and longitude $47^{\circ} 27^{\prime}$ West; it is intersected by the major highways of Castello Branco and Raposo Tavares that are heavily used by buses and trucks. Sorocaba has approximately 600 thousand inhabitants (IBGE, 2013), an industrial complex of just over 1,700 industries (Sorocaba, 2013), and a fleet of vehicles of about 200,000 cars and 60,000 motorcycles (IBGE, 2013).

This study included both sexes, aged over 50 years, residents of the city of Sorocaba. The study included the period from January 1, 2007 to December 31, 2011. Hospital admission data were obtained through the DATASUS site of the Hospital Information System (SIH) of the Unified Health System (SUS).

Data regarding daily levels of air pollutants concentrations, the average temperature and average relative humidity of air were supplied by the Environmental Agency of São Paulo (CETESB) in Sorocaba, which has a monitoring station located downtown. This station estimates the daily averages of particulate matter $\left(\mathrm{PM}_{10}\right)$, and the maximum values of ozone $\left(\mathrm{O}_{3}\right)$, nitrogen dioxide $\left(\mathrm{NO}_{2}\right)$ and nitrogen oxide $(\mathrm{NO})$ over 24 hours. The apparent temperature was used in this article because this variable considers average temperature and average relative humidity, (Barnett et al., 2010).

The number of daily admissions was the dependent variable and the levels of $\mathrm{PM}_{10}, \mathrm{O}_{3}$, $\mathrm{NO}_{2}$ and $\mathrm{NO}$, quantified in $\mu \mathrm{g} \mathrm{m}^{-3}$, were the independent variables and were adjusted for the daily apparent temperature.

An initial descriptive analysis of each variable was conducted in terms of average values, minimum, maximum and standard deviation, and Pearson correlation coefficients were calculated to identify the correlation between exposure to air pollutants, apparent temperature, and hospitalizations.

The study used the generalized additive model (GAM) of Poisson regression. This model is an alternative to modeling nonlinear relationships that require a smaller number of explanatory variables. Furthermore, the GAM is used to calculate the relative risk, given that the outcome is a discrete variable, a rare event (Conceição et al., 2001).

Stroke morbidity may apparently be distributed over time due to a lag between hospitalization and the individual's exposure to concentrations of the air pollutants; therefore, hospitalizations observed on a particular day may be due to exposure to air pollutants not only this same day, but over the previous days. Nevertheless, there is no consensus regarding a limit of variations for day lag. Therefore, the study chose to investigate this pattern, including daily concentrations of $\mathrm{PM}_{10}, \mathrm{O}_{3}, \mathrm{NO}_{2}$ and $\mathrm{NO}$ ranging from the present day (lag 0) until five days before the hospitalization (lag 5). 
The coefficients provided by GAM were transformed into relative risks (RR) to hospitalization. The risks of hospitalizations and percentage increase in these risks were estimated according to the increment of $10 \mu \mathrm{g} \mathrm{m}{ }^{3}$ for each air pollutant.

We applied the following expression to estimate the percentage increase (PI): $\mathrm{PI}=(\mathrm{RR}-1) \mathrm{x} 100$, where RR is defined as [exp (coef $* 10)]$, where coef is the coefficient given by Poisson regression, in which $10 \mu \mathrm{g} \mathrm{m}-^{3}$ were added to concentrations of air pollutants. Analyses were performed by SPSS v 17 and Statistica v. 7 software.

\section{RESULTS AND DISCUSSION}

Data from 2047 hospitalizations due to stroke during the study period were obtained; 1083 hospitalizations were of men and 966 were of women. The minimum and maximum values, averages and standard deviations are presented in Table 1.

Table 1. Descriptive analysis of hospital admissions due to stroke, concentrations of air pollutants and climate variable. Sorocaba, SP, Brazil, 2007 to 2011.

\begin{tabular}{lccc}
\hline & Mean (SD) & Minimum & Maximum \\
\hline Hospital admission & $1.1(1.1)$ & 0 & 7 \\
$\mathrm{PM}_{10}\left(\mu \mathrm{g} \mathrm{m}^{-3}\right)$ & $32.5(17.3)$ & 6 & 116 \\
$\mathrm{O}_{3}\left(\mu \mathrm{g} \mathrm{m}^{-3}\right)$ & $79.9(30.1)$ & 4 & 199 \\
$\mathrm{NO}_{2}\left(\mu \mathrm{g} \mathrm{m}^{-3}\right)$ & $45.9(27.2)$ & 6 & 158 \\
$\mathrm{NO}\left(\mu \mathrm{g} \mathrm{m}^{-3}\right)$ & $48.2(55.2)$ & 0 & 333 \\
Apparent temperature $\left({ }^{0} \mathrm{C}\right)$ & $24.5(4.0)$ & 11.2 & 33.5 \\
\hline
\end{tabular}

$\mathrm{SD}=$ standard deviation.

There was a lack of data from independent variables ranging from 5.53 to $9.04 \%$, but the missing data were randomly distributed over the entire period. On the other hand, the details of admissions due to stroke were available on all of the days of the study.

The means of $\mathrm{PM}_{10}$ and $\mathrm{NO}_{2}$ did not exceed the annual air quality standards, $50 \mu \mathrm{g} \mathrm{m}^{-3}$ and $100 \mu \mathrm{g} \mathrm{m}^{-3}$, respectively, established in 1990 by the Brazilian National Environmental Council (CONAMA) (Brazil, 1990). Nevertheless, the mean of $\mathrm{O}_{3}$ had 15 values exceeding the established limit throughout the study.

The distribution of the daily levels of air pollutants is shown in Figure 1. A seasonal pattern was observed, with the highest values in daily concentrations for $\mathrm{PM}_{10}, \mathrm{NO}_{2}$ and $\mathrm{NO}$ during the winter months. Nevertheless, the daily $\mathrm{O}_{3}$ concentrations showed an erratic pattern.

Several studies used the average temperature and relative humidity (Tsai et al., 2003; Cendon et al., 2006; Gouveia et al., 2006; Braga et al., 2007; Andersen et al., 2010; Ignotti et al., 2010; Nascimento, 2011; Amancio and Nascimento 2012; Nascimento et al., 2012), but Barnett et al. (2010) argue that the apparent temperature is the best fit for such modeling. This study also used the apparent temperature, as did Wellenius et al. (2005).

The correlations between the study variables are shown in Table 2 . 

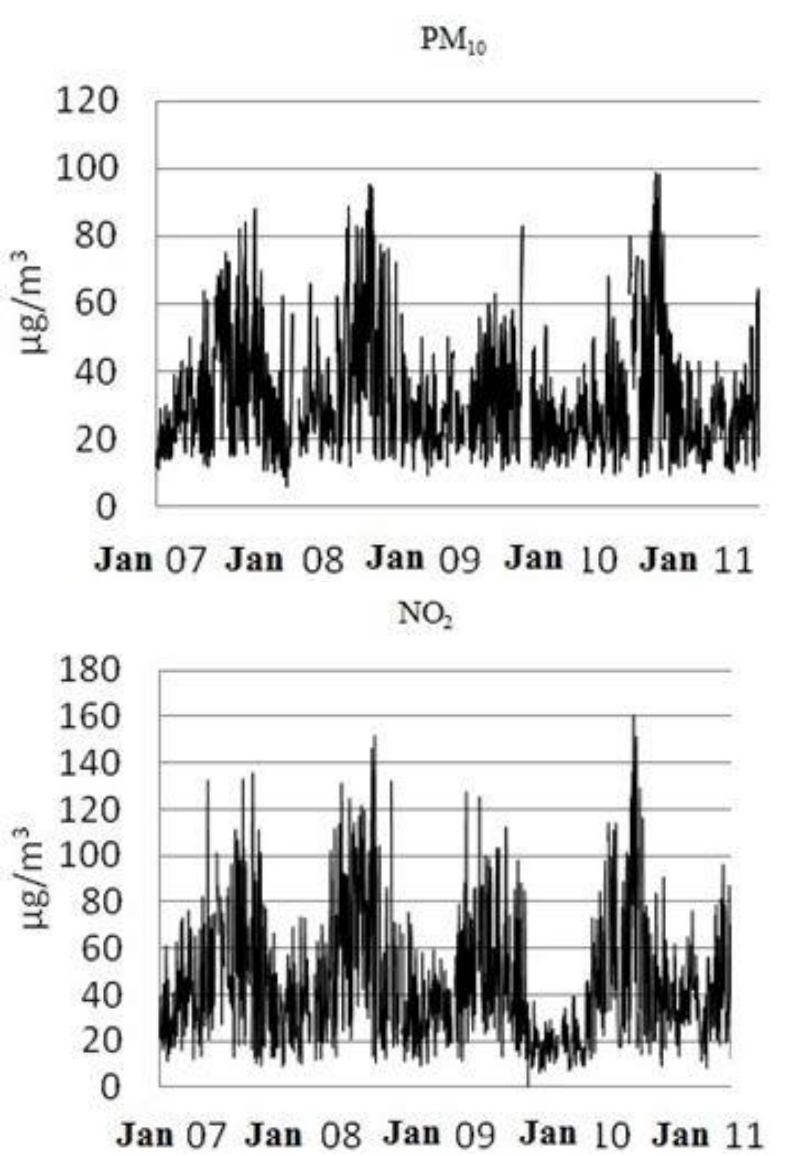

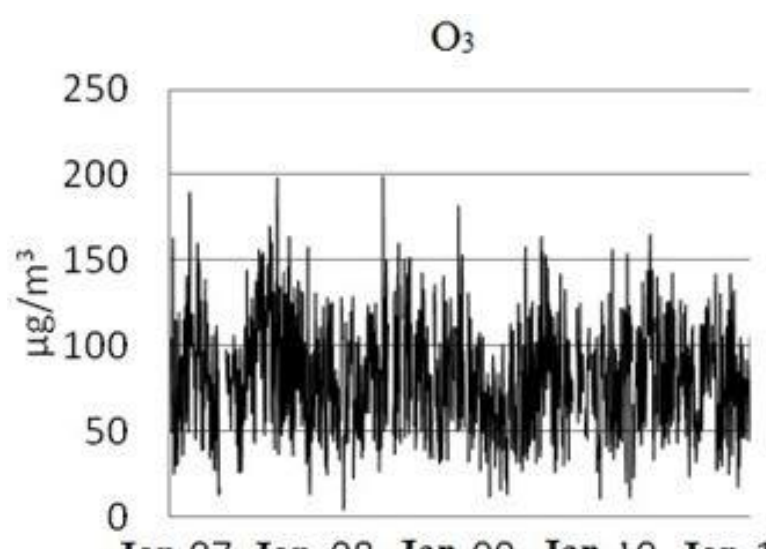

Jan 07 Jan 08 Jan 09 Jan 10 Jan 11

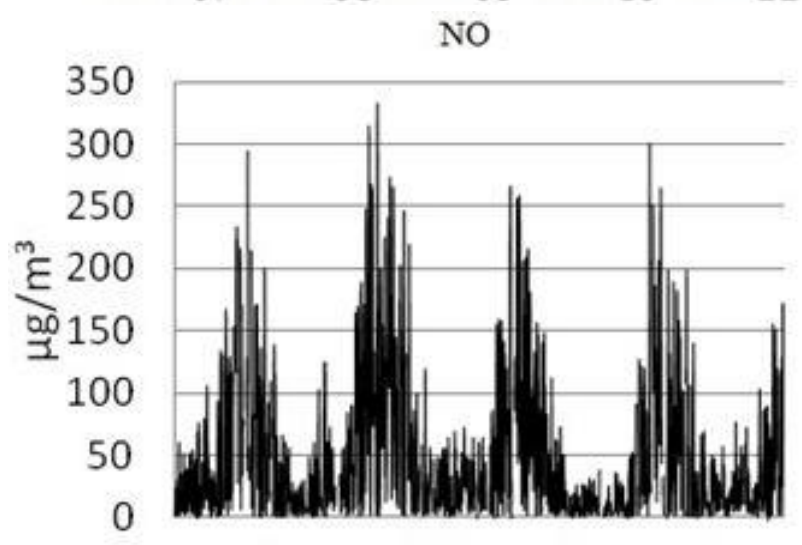

Jan 07 Jan 08 Jan 09 Jan 10 Jan 11

Figure 1. Distribution of daily concentrations of particulate matter, ozone, nitrogen dioxide and nitrogen oxide in Sorocaba, SP, Brazil, 2007-2011.

Table 2. Pearson correlation matrix of concentrations of air pollutants, meteorological variable and hospitalizations. Sorocaba, SP, Brazil, 2007 to 2011.

\begin{tabular}{lllllll}
\hline & $\mathrm{HA}$ & $\mathrm{PM}_{10}$ & \multicolumn{1}{c}{$\mathrm{O}_{3}$} & $\mathrm{NO}_{2}$ & $\mathrm{NO}$ & $\mathrm{AT}$ \\
\hline $\mathrm{HA}$ & 1.00 & & & & & \\
$\mathrm{PM}_{10}$ & 0.02 & 1.00 & & & & \\
$\mathrm{O}_{3}$ & -0.01 & $0.47^{* *}$ & 1.00 & & & \\
$\mathrm{NO}_{2}$ & $0.05^{*}$ & $0.83^{* *}$ & $0.37^{* *}$ & 1.00 & & \\
$\mathrm{NO}$ & $0.05^{*}$ & $0.71^{* *}$ & $0.17^{* *}$ & $0.75^{* *}$ & 1.00 & \\
$\mathrm{AT}$ & -0.02 & $0.27^{* *}$ & $0.65^{* *}$ & $0.14^{* *}$ & -0.03 & 1.00 \\
\hline
\end{tabular}

$\mathrm{AT}=$ apparent temperature; $\mathrm{HA}=$ hospital admission; ** p-value $<0.01 ; *$ p-value $<0.05$.

This work used the generalized additive model instead of the generalized linear model, similar to the study by Amancio and Nascimento (2012). The use of GAM is justified by incorporating information about seasonal changes and trends between hospitalizations and climatic variables for this time series study (Conceição et al., 2001).

Table 3 shows the coefficients of air pollutants studied and their respective standard errors obtained by generalized additive model of Poisson regression from the lag of 0 up to the lag of 5. Significant association (p-value $<0.05$ ) between exposure to nitrogen dioxide and hospitalizations due to stroke was observed after just three days exposure before admission (lag 3). 
Table 3. Regression coefficients provided by the model for pollutants adjusted for apparent temperature, with the respective standard errors according lags 0-5 days for hospitalizations due to strokes. Sorocaba, SP, Brazil, 2007 to 2011.

\begin{tabular}{|c|c|c|}
\hline & & Coefficient (SE) \\
\hline \multicolumn{3}{|l|}{$\mathrm{PM}_{10}$} \\
\hline & Lag 0 & $-0.00289(0.00284)$ \\
\hline & Lag 1 & $-0.00121(0.00285)$ \\
\hline & Lag 2 & $0.00137(0.00286)$ \\
\hline & Lag 3 & $-0.00380(0.00286)$ \\
\hline & $\operatorname{Lag} 4$ & $0.00073(0.00285)$ \\
\hline & Lag 5 & $0.00338(0.00283)$ \\
\hline \multicolumn{3}{|l|}{$\mathrm{O}_{3}$} \\
\hline & Lag 0 & $0.00024(0.00120)$ \\
\hline & Lag 1 & $0.00016(0.00116)$ \\
\hline & Lag 2 & $0.00039(0.00118)$ \\
\hline & Lag 3 & $-0.00099(0.00119)$ \\
\hline & $\operatorname{Lag} 4$ & $0.00136(0.00117)$ \\
\hline & Lag 5 & $-0.00040(0.00116)$ \\
\hline \multicolumn{3}{|l|}{$\mathrm{NO}_{2}$} \\
\hline & Lag 0 & $0.00167(0.00178)$ \\
\hline & Lag 1 & $-0.00004(0.00177)$ \\
\hline & Lag 2 & $0.00028(0.00179)$ \\
\hline & Lag 3 & $0.00394(0.00179)^{\#}$ \\
\hline & Lag 4 & $-0.00252(0.00181)$ \\
\hline & Lag 5 & $-0.00058(0.00178)$ \\
\hline \multicolumn{3}{|l|}{ NO } \\
\hline & Lag 0 & $0.00066(0.00073)$ \\
\hline & Lag 1 & $0.00090(0.00071)$ \\
\hline & Lag 2 & $-0.00029(0.00074)$ \\
\hline & Lag 3 & $-0.00053(0.00075)$ \\
\hline & Lag 4 & $0.00075(0.00073)$ \\
\hline & Lag 5 & $-0.00010(0.00072)$ \\
\hline
\end{tabular}

${ }^{\#}$ p-value $<0.05$

Figure 2 shows the relative risk (RR) for hospitalization in accordance with increment of $10 \mu \mathrm{g} \mathrm{m}^{-3}$ in daily average concentrations of each air pollutant and $95 \%$ confidence intervals. 


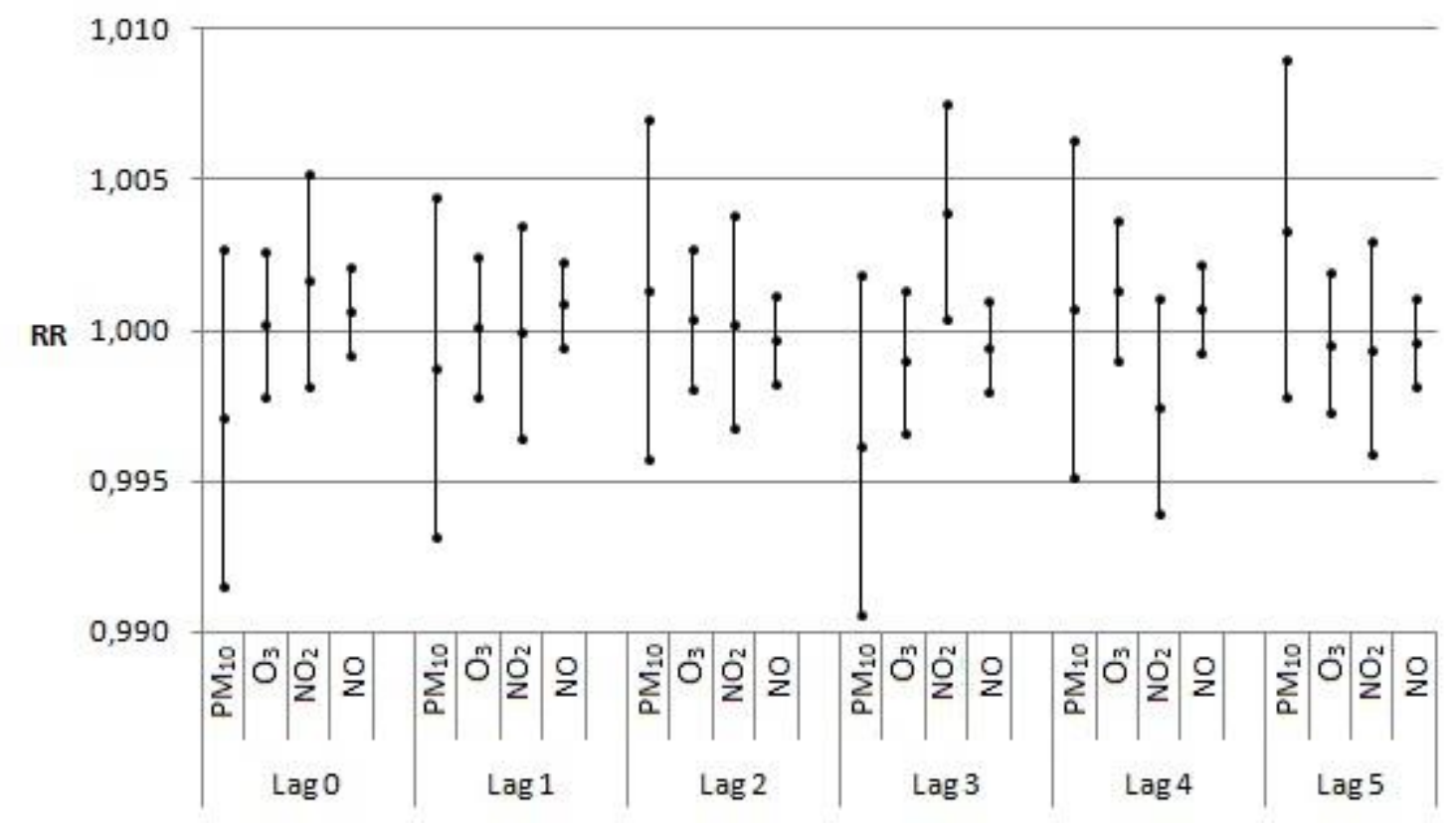

Figure 2. Relative risks (RR) for the increment of $10 \mu \mathrm{g} \mathrm{m}^{-3}$ and $95 \%$ confidence interval for hospitalizations due to stroke at the exposure of pollutants study adjusted by apparent temperature in each lag structure. Sorocaba, SP, Brazil, 2007 to 2011.

We notice that the RR for hospitalizations due to strokes was small. Furthermore, exposure to inhalable particulate matter, ozone and nitrogen oxide showed no significant association with the values of hospital admissions for stroke. On the other hand, nitrogen dioxide showed a significant result.

In our study model, the relative risk to hospitalizations due to strokes after exposure to $\mathrm{NO}_{2}$ reached $1.004(95 \%$ CI $1.000-1.008)$ in the third day lag. This RR estimated an increase of 4 percentage points for the total admissions due to stroke, when considering $10 \mu \mathrm{g} \mathrm{m}^{-3}$ increase in the concentration of this pollutant.

Despite the small magnitude of the RR obtained in this study, the impact of air pollutants on human health must be considered due to the large number of individuals exposed.

A 10-year cohort study with control variables conducted in London (Maheswaran et al., 2010) showed that patients who suffered the first stroke had reduced survival under high concentrations of the pollutants studied. Increased mortality after stroke was observed after exposure to $\mathrm{PM}_{10}$ and $\mathrm{NO}_{2}$, but it was more significant for $\mathrm{NO}_{2}$, which is related to vehicular traffic. An increase of $10 \mu \mathrm{g} \mathrm{m}^{-3}$ in $\mathrm{NO}_{2}$ concentrations was associated with an increase of $28 \%$ (95\% CI 11\% - 48\%) in mortality risk, according to these authors.

Another study carried out in nine U.S. cities (Wellenius et al., 2005) identified an association between exposure to air pollutants and increased admissions on the same day. A $2.94 \%$ (1.78 to 4.12 ) percentage increase in the rate of hospitalization due to ischemic stroke after exposure to $\mathrm{NO}_{2}$ was observed, but no association was observed between exposure to any air pollutant and hospitalizations due to hemorrhagic in lags of 0 up to lags of 2 . However, our study did not observe the acute effect in the associations between air pollutants and hospital admissions due to stroke.

Moreover, exposure to nitrogen dioxide was associated with admissions, denoting a more severe picture in a prospective cohort study (Andersen et al., 2012). The study identified significant associations between $\mathrm{NO}_{2}$ exposure and stroke incidence and also fatal stroke 
during a follow-up of about 10 years. The associations were stronger for the ischemic and unspecified stroke, whereas no association was detected with hemorrhagic stroke.

However, a study in London (Maheswaran et al., 2012) identified no association between $\mathrm{NO}_{2}$ exposure and incidence of hemorrhagic, ischemic and total stroke. Only borderline values of rate ratio of 1.23 (95\% CI 0.99 - 1.53) for $10 \mu \mathrm{g} \mathrm{m}^{-3}$ increase in concentration of the pollutant $\mathrm{NO}_{2}$ were noted, considering people 65 to 79 years old.

A similar study carried out in Copenhagen, Denmark, used a case-crossover model, a variant of case-control, with temporal stratification to study the effects of temporary exposures in acute events (Andersen et al., 2010), and found that ultrafine particles - $\mathrm{PM}_{0,1^{-}}$ (particles $<0.1 \mathrm{~mm}$ in diameter) acted as a risk factor for hospital admissions due to ischemic stroke. In the present study, it was impossible to analyze ultrafine particles, since they were not monitored by our source, the CETESB.

A similar study carried out in São José dos Campos, São Paulo, Brazil, a medium-size city (Nascimento et al., 2012), identified the association of particulate matter exposure on the same day with hospitalization due to stroke. A multi-pollutant model estimated a significant relative risk of 1.013. This study showed the average daily value of $\mathrm{PM}_{10}$ in $24 \mu \mathrm{g} \mathrm{m}^{-3}$, while the present study showed $32.5 \mu^{-3}$ while excluding the pollutant $\mathrm{NO}_{2}$ from its investigation. In this study, the inclusion of $\mathrm{NO}_{2}$ concentrations in Sorocaba in the analysis may have better suited the model; the particulate material does not appear as a risk factor for stroke hospitalization. The findings in Sorocaba coincide with the data of Maheswaran et al. (2010) who also did not identify an association between $\mathrm{PM}_{10}$ and the incidence of stroke.

A study carried out in Taiwan (Tsai et al., 2003) detected the association between $\mathrm{NO}_{2}$ and admissions due to stroke. An average $\mathrm{NO}_{2}$ concentration of $28.2 \mu \mathrm{g} \mathrm{m}^{-3}$ was used, almost half of the concentration compared with our study, which used $45.9 \mu \mathrm{g} \mathrm{m}^{-3}$. Positive associations for the pollutants under study for both ischemic and hemorrhagic stroke were identified for single-pollutant models, on hot days ( $\left.\mathrm{T}>20^{\circ} \mathrm{C}\right)$. A model considering exposure to two pollutants, $\mathrm{PM}_{10}$ and $\mathrm{NO}_{2}$, and hospital admissions for both types of stroke on hot days showed a statistically positive association. On the other hand, the effects of $\mathrm{CO}$, sulfur dioxide $\left(\mathrm{SO}_{2}\right)$ and $\mathrm{O}_{3}$ were not significant when $\mathrm{NO}_{2}$ was included in the analysis (Tsai et al., 2003).

In this paper it was impossible to assess the role of $\mathrm{SO}_{2}$ exposure, although studies (Tsai et al., 2003; Nascimento et al., 2012) present relative risks of exposure to this air pollutant in uni-pollutant models, because the source monitoring, CETESB, was missing $\mathrm{SO}_{2}$ data for most days.

Although there has been high Pearson correlation between pollutants and apparent temperature, the same was not observed for hospitalizations; this may have contributed to the result that there was no association between hospital admissions due to stroke in all lags.

The present study used data from DATASUS, as did other studies (Cendon et al., 2006; Gouveia et al., 2006; Nascimento, 2011; Amancio and Nascimento, 2012; Nascimento et al., 2012). Despite the incomplete coverage of hospitalizations and the uncertainties regarding the reliability of information contained in Hospital Information System (SIH / SUS), a variety of studies were found showing internal consistence and coherence with current knowledge (Veras and Martins, 1994; Bittencourt et al., 2006).

As in other studies, this paper found in impossible to identify an association between air pollutants and hospital admissions due to ischemic or hemorrhagic stroke (Tsai et al., 2003; Wellenius et al., 2005; Andersen et al., 2010; Johnson et al., 2010; Maheswaran et al., 2012). Despite the fact that DATASUS data classifies stroke hospitalizations by stroke subtypes, ischemic or hemorrhagic, most stroke diagnoses are not specified because the data from DATASUS is collected for economic rather than epidemiological purposes. 
Hopitalization was the analyzed outcome of the present study; but hospitalization is just one of the many negative effects of air pollution.

Still, the data provided by DATASUS did not include associated diseases such as hypertension, hypercholesterolemia, physical inactivity, smoking and other co-morbidities that may interfere the stroke occurrence. On the other hand, Johnson et al. (2010) did not observe significant differences when the admissions were controlled for smoking, high blood pressure and body mass index.

This study has limitations, such as the limitations of time series ecological studies which lack individual information on exposure and disease; information is presented in the aggregateas whole populations are studied. It therefore cannot be said that hospitalized individuals were really exposed to levels of air pollution. Also, the study assumes homogeneous exposure throughout the city and that all individuals were similarly exposed. Moreover, daily basis ecological studies show factors whose distributions do not vary daily, and so could not act as potential confounders.

Another limitation of this study is that it uses records related to hospitalizations in the public health system. Thus, the results reflected the effects of air pollutants on the population that uses the network of the Unified Health System, i.e., the majority of the Brazilian population.

There may be some degree of underestimation regarding the frequency of certain complaints, considering the technological profile of the healthcare network and also the possibility of errors in coding of diagnoses. However, the diagnostic confirmation of hospitalizations is performed later in order to reduce diagnostic errors. Another problem may be the double counting of the same patient, since the system does not identify hospitalizations.

It should be noted that even at concentrations below those recommended by CONAMA, an increase in hospital admissions due to stroke is associated with exposure to high concentrations of $\mathrm{NO}_{2}$.

\section{CONCLUSION}

It is expected that the results of this study will serve as a reference for further exploration of exposure to other pollutants and hospital admissions due to stroke. Furthermore, it was possible to identify the long-term effect of exposure to $\mathrm{NO}_{2}$ on hospitalizations due to stroke even in concentrations considered acceptable. If public policy encouraged a reduction in concentrations, the number of hospitalizations due to stroke could likewise be reduced.

\section{REFERENCES}

AMANCIO, C. T.; NASCIMENTO, L. F. C. Asthma and air pollutants: a time series study. Revista da Associação Médica Brasileira, v. 58, n. 3, p. 302-307, 2012. http://dx.doi.org/10.1590/S0104-42302012000300009

ANDERSEN, Z. J.; KRISTIANSEN, L. C.; ANDERSEN, K. K.; OLSEN, T. S.; HVIDBERG, M.; JENSEN, S. S. et al. Stroke and Long-Term Exposure to Outdoor Air Pollution From Nitrogen Dioxide : A Cohort Study. Stroke, v. 43, n. 2, p. 320-325, 2012. http://dx.doi.org/10.1161/STROKEAHA.111.629246

ANDERSEN, Z. J.; OLSEN, T. S.; ANDERSEN, K. K.; LOFT, S.; KETZEL, M.; RAASCHOU-NIELSEN, O. Association between short-term exposure to ultrafine particles and hospital admissions for stroke in Copenhagen, Denmark. European Heart Journal, v. 31, n. 16, p. 2034-2040, 2010. http://dx.doi.org/10.1093/eurheartj/ehq188 
BARNETT, A. G.; TONG, S.; CLEMENTS, A. C. A. What measure of temperature is the best predictor of mortality? Environmental Research, v. 110, n. 6, p. 604-611, 2010. http://dx.doi.org/10.1016/j.envres.2010.05.006

BITTENCOURT, A. S.; CAMACHO, L. A. B.; LEAL, M. C. O Sistema de Informação Hospitalar e a sua aplicação na saúde coletiva. Cadernos de Saúde Pública, v. 22, n. 1, p. 19-30, 2006. http://dx.doi.org/10.1590/S0102-311X2006000100003

BRAGA, A. L. F.; PEREIRA, L. A. A.; PROCÓPIO, M.; ANDRÉ, P. A.; SALDIVA, P. H. N. Association between air pollution and respiratory and cardiovascular diseases in Itabira, Minas Gerais State, Brazil. Cadernos de Saúde Pública, v. 23, supl. 4, p. 570578, 2007. http://dx.doi.org/10.1590/S0102-311X2007001600017

BRASIL. Ministério do Meio Ambiente. Resolução CONAMA No 003/1990. Disponível em: http://www.mma.gov.br/port/conama/legiabre.cfm?codlegi=100. Access in: 20 May 2014.

BRASIL. Ministério da Saúde. Banco de dados do Sistema Único de Saúde. DATASUS. Informações de Saúde. Epidemiológicas e morbidade. Disponível em: <http://tabnet.datasus.gov.br/cgi/deftohtm.exe?sih/cnv/niuf.def>. Access in: 20 Apr. 2013

BROOK, R. D.; FRANKLIN, B.; CASCIO, W.; HONG, Y.; HOWARD, G.; LIPSETT, M. et al. Air pollution and cardiovascular disease: a statement for healthcare professionals from the Expert Panel on Population and Prevention Science of the American Heart Association. Circulation, v. 109, n. 21, p. 2655-2671, 2004. http://dx.doi.org/10. 1161/01.CIR.0000128587.30041.C8

CANÇADO, J. E. D.; BRAGA, A.; PEREIRA, L. A. A.; ARBEX, M.A.; SALDIVA, P. H. N.; SANTOS, U. D. P. Clinical repercussions of exposure to atmospheric pollution. Jornal Brasileiro de Pneumologia, v. 32, supl. 2, p. 5-11, 2006. http://dx.doi.org/10.1590/S1806-37132006000800003

CENDON, S.; PEREIRA, L. A. A.; BRAGA, A. L. F.; CONCEIÇÃO, G. M. S.; CURY Jr, A.; ROMALDINI, H. et al. Air pollution effects on myocardial infarction. Revista de Saúde Pública, v. 40, n. 3, p. 41-419, 2006. http://dx.doi.org/10.1590/S003489102006000300008

CONCEIÇÃO, G. M. S.; SALDIVA, P. H. N.; SINGER, J. M. Modelos MLG e MAG para análise da associação entre poluição atmosférica e marcadores de morbi-mortalidade: uma introdução baseada em dados da cidade de São Paulo. Revista Brasileira de Epidemiologia, v. 4, n. 3, p. 206-219, 2001. http://dx.doi.org/10.1590/S1415790X2001000300007

DONNAN, G. A.; FISHER, M.; MACLEOD, M.; DAVIS, S. M. Stroke. The Lancet, v. 371, p. 1612-1623, 2008. http://dx.doi.org/10.1016/S0140-6736(08)60694-7

GAVINIER, S.; NASCIMENTO, L. F. C. Material particulado e internações por doenças isquêmicas do coração em Sorocaba, SP. Rev. Ambient. Água vol. 8 (suplemento), p.228-236, 2013. http://dx.doi.org/10.4136/ambi-agua.1418

GOUVEIA, N.; FREITAS, C. U.; MARTINS, L. C.; MARCILIO, I. O. Hospitalizações por causas respiratórias e cardiovasculares associadas à contaminação atmosférica no Município de São Paulo, Brasil. Cadernos de Saúde Pública, v. 22, n. 12, p. 26692677, 2006. http://dx.doi.org/10.1590/S0102-311X2006001200016 
HARRISON, R. M. Air quality guidelines: global update 2005. Sources of air pollution, 2006. 9p.

HONG, Y. C.; LEE, J. T.; KIM, H.; KWON, H. J. Air pollution: a new risk factor in ischemic stroke mortality. Stroke, v. 33, n. 9, p. 2165-2169, 2002. http://dx.doi.org/10.1161/01.STR.0000026865.52610.5B

IGNOTTI, E.; VALENTE, J. G.; LONGO, K. M.; FREITAS, S. P.; HACON, S. S.; NETTO, P. A. Impact on human health of particulate matter emitted from burnings in the Brazilian Amazon region. Revista de Saúde Pública, v. 44, n. 1, p. 121-130, 2010. http://dx.doi.org/10.1590/S0034-89102010000100013

INSTITUTO BRASILEIRO DE GEOGRAFIA E ESTATÍSTICA - IBGE. Cidades. Available in: <http://cidades.ibge.gov.br/xtras/perfil.php?lang=\&codmun=355220\& search=sao-paulo|sorocaba $>$. Access in: 26 Nov. 2013.

JOHNSON, J. Y. M.; ROWE, B. H.; VILLENEUVE, P. J. Ecological analysis of long-term exposure to ambient air pollution and incidence of stroke in Edmonton, Alberta, Canada. Stroke, v. 41, n. 7, p. 1319-1325, 2010. http://dx.doi.org/10. 1161/STROKEAHA.110.580571

LOTUFO, P. A. Stroke in Brazil: a neglected disease. Sao Paulo Medical Jounal, v. 123, n. 1, p. 3-4, 2005. http://dx.doi.org/10.1590/S1516-31802005000100001

MAHESWARAN, R.; PEARSON, T.; SMEETON, N. C.; BEEVERS, S. D.; CAMPBELL, M. J.; WOLFE, C. D. Outdoor air pollution and incidence of ischemic and hemorrhagic stroke: a small-area level ecological study. Stroke, v. 43, n. 1, p. 22-27, 2012. http://dx.doi.org/10.1161/STROKEAHA.110.610238

MAHESWARAN, R.; PEARSON, T.; SMEETON, N. C.; BEEVERS, S. D.; CAMPBELL, M. J.; WOLFE, C. D. Impact of outdoor air pollution on survival after stroke: population-based cohort study. Stroke, v. 41, n. 5, p. 869-877, 2010. http://dx.doi.org/10.1161/STROKEAHA.109.567743

NASCIMENTO, L. F. C. Air pollution and cardiovascular hospital admissions in a mediumsized city in São Paulo State, Brazil. Brazilian Journal of Medical and Biological Research, v. 44, n. 7, p. 720-724, 2011. http://dx.doi.org/10.1590/S0100879X2011007500079

NASCIMENTO, L. F. C.; FRANCISCO, J. B.; PATTO, M. B. R.; ANTUNES, A. M. Environmental pollutants and stroke-related hospital admissions. Cadernos de Saúde Pública, v. 28, n. 7, p. 1319-1324, 2012. http://dx.doi.org/10.1590/S0102311X2012000700010

OLMO, N. R. S.; SALDIVA P. H. N.; BRAGA, A. L. F.; LIN, C. A.; SANTOS, U. P.; PEREIRA, L. A. A. A review of low-level air pollution and adverse effects on human health: implications for epidemiological studies and public policy. Clinics, v. 66, n. 4, p. 681-690, 2011. http://dx.doi.org/10.1590/S1807-59322011000400025

POPE, C. A.; BURNeTt, R. T.; THURSTON, G. D.; THUN, M. J.; CALlE, E. E.; KREWSKI, D.; GODLESKI, J. J. Cardiovascular mortality and long-term exposure to particulate air pollution: epidemiological evidence of general pathophysiological pathways of disease. Circulation, v. 109, n. 1, p. 71-77, 2004. http://dx.doi.org/10.1161/01.CIR.0000108927.80044.7F 
SOROCABA. A cidade de Sorocaba. Disponível em: <http://www.sorocaba.com.br/sobresorocaba>. Access in: 26 Nov. 2013.

TSAI, S. S.; GOGGINS, W. B.; CHIU, H. F.; YANG, C. Y. Evidence for an association between air pollution and daily stroke admissions in Kaohsiung, Taiwan. Stroke, v. 34, n. 11, p. 2612-2616, 2003. http://dx.doi.org/10.1161/01.STR.0000095564.33543.64

VERAS, C.; MARTINS, M. A confiabilidade dos dados nos formulários de Autorização de Internação Hospitalar, Rio de Janeiro, Brasil. Cadernos de Saúde Pública, v. 10, n. 3, p. 339-355, 1994.

WELlENiUS, G. A.; SCHWARTZ, J.; MITTLEMAN, M. A. Air pollution and hospital admissions for ischemic and hemorrhagic stroke among medicare beneficiaries. Stroke, v. 36, n. 12, p. 2549-2553, 2005. http://dx.doi.org/10.1161/01.STR.0000189687 .78760 .47 